\title{
DR-16. GREEN APPROACH FOR THE SYNTHESIS OF SOME NEW DIAMIDOMETHANE LINKED PYRIDINYL PYRAZOLES
}

G. Yamini ${ }^{1}$, T. Sreenivasulu ${ }^{1}$, G. Sravya ${ }^{2}$, A. Padmaja ${ }^{1}$, G. V. Zyryanov ${ }^{2,3}$

${ }^{1}$ Department ofChemistry, Sri Venkateswara University, Tirupati, Andhra Pradesh, 517502, India

${ }^{2}$ Ural Federal University of the first President of Russia B. N. Yeltsin, Mira St., 19, Yekaterinburg, 620002, Russia

${ }^{3}$ I. Ya. Postovsky Institute of Organic Synthesis UB RAS, S. Kovalevskoy / Akademicheskaya St., 20/22, Yekaterinburg, 620990, Russia E-mail: adivireddyp@yahoo.co.in

Some new diamidomethane linked pyridinyl pyrazoles was synthesized by adopting 1,3-dipolar cycloaddition of nitrile imines generated from araldehydephenylhydrazones in the presence of iodosobenzene and CTAB followed by oxidation with $\mathrm{I}_{2}$ in DMSO. All the compounds were characterized by spectral parameters.<smiles>N#Cc1c(Br)cc([Al])nc1NC(=O)CNC(=O)/C=C/c1ccccc1</smiles><smiles>C=[13CH]</smiles><smiles>Cc1c(C#N)cc([Al])nc1NC(=O)CNC(=O)c1c(-c2ccccc2)nn(-c2ccccc2)c1-c1ccccc1</smiles>

Ar' $\mathrm{Ph}$ $4-\mathrm{OMe} \cdot \mathrm{Ph}$ $4-\mathrm{OMe} \cdot \mathrm{Ph}$ $\mathrm{Ph}$

$\mathrm{Ph}$ 